\title{
Coxa saltans misdiagnosed as functional gait disorder
}

\section{Two cases}

Donald L. Gilbert, MD, MS, Alberto J. Espay, MD, MSc, and Steve W. Wu, MD

Correspondence

Neurology ${ }^{\circledR}$ 2018;91:276-277. doi:10.1212/WNL.0000000000005955

Dr. Wu

steve.wu@cchmc.org

Figure Anatomy of coxa saltans
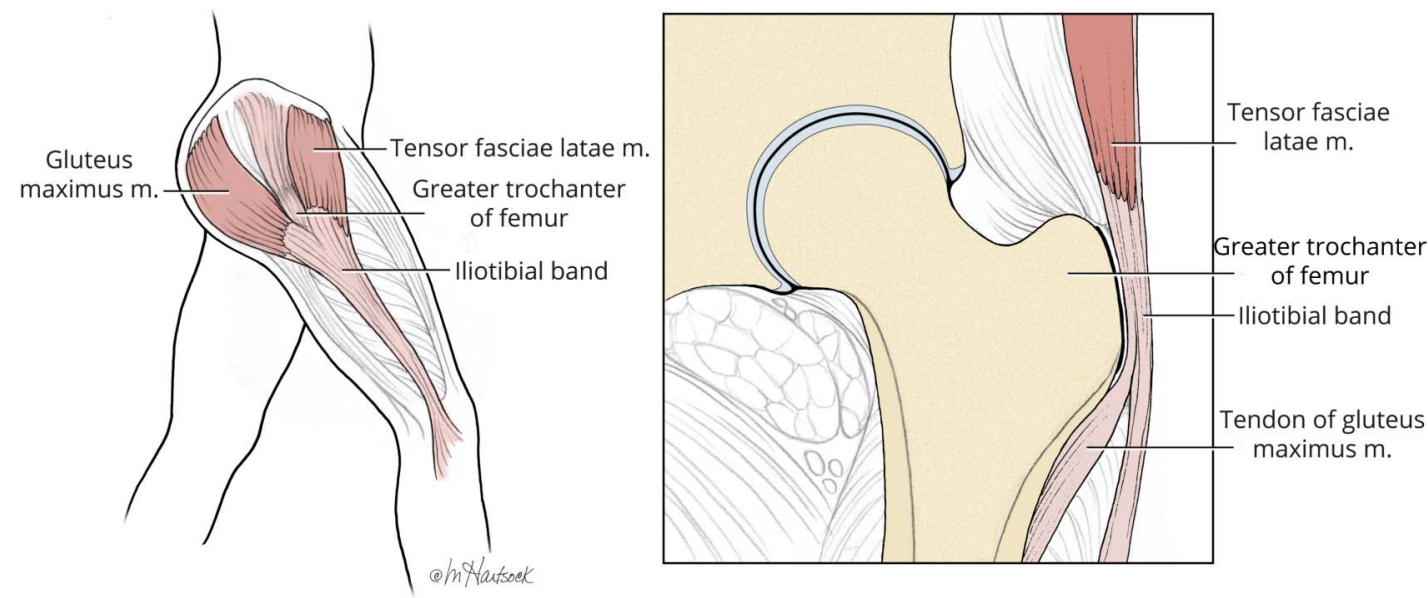

Sagittal (left) and coronal (right) view of the relationship between the gluteus maximum tendon, iliotibial band, and tensor fascia lata with the greater trochanter.

Two unrelated young girls were evaluated for a gait suspected to be functional (video). Hip movements during ambulation were excessive despite normal tone, strength, sensation, and muscle stretch reflexes. Ascertainment of joint hypermobility led to the diagnosis of Ehlers-Danlos syndrome in both. Coxa saltans, also known as "dancer's hip" or "snapping hip," may develop among young athletes with clicking joints due to connective tissue disorders. ${ }^{1}$ The gluteus maximum tendon, iliotibial band, or tensor fascia lata slide back and forth across the greater trochanter during flexion-extension movements in external coxa saltans (figure). Case 1 required bilateral iliotibial band lengthening surgery. ${ }^{2}$

\section{Author contributions}

Drs. Gilbert and $\mathrm{Wu}$ : acquisition of data, analysis and interpretation, critical revision of the manuscript for important intellectual content. Dr. Espay: report analysis and interpretation, critical revision of the manuscript for important intellectual content.

\section{Acknowledgment}

The authors thank Marcia Hartsock, MA, CMI, for the original illustration detailing the hip anatomy in the figure.

From the Division of Neurology, Department of Pediatrics (D.L.G., S.W.W.), Cincinnati Children's Hospital Medical Center and University of Cincinnati; and Department of Neurology (A. J.E.), Gardner Center for Parkinson's Disease and Movement Disorders, UC Gardner Neuroscience Institute, University of Cincinnati, OH.

Go to Neurology.org/N for full disclosures. Funding information and disclosures deemed relevant by the authors, if any, are provided at the end of the article. 


\section{Study funding}

No targeted funding reported.

\section{Disclosure}

D. Gilbert has received honoraria and/or travel support from the Tourette Association of America/Centers for Disease Control and Prevention, the American Academy of Pediatrics, and the Child Neurology Society. He has received book royalties from Elsevier and Wolters Kluwer. He has received compensation for expert testimony for the US DOJ DVIC program. Dr. Gilbert has received research support from the NIH (NIMH, NINDS). He has received funding for work as a clinical trial site investigator from Ecopipam Pharmaceuticals (clinical trial, Tourette syndrome) and EryDel (clinical trial, ataxia-telangiectasia). A. Espay has received grant support from the NIH, Great Lakes Neurotechnologies, and the Michael J. Fox Foundation; personal compensation as a consultant/scientific advisory board member for AbbVie, TEVA, Impax, Acadia, Acorda, Cynapsus/Sunovion, Lundbeck, and USWorldMeds; publishing royalties from Lippincott Williams \& Wilkins, Cambridge University Press, and Springer; and honoraria from AbbVie, UCB, USWorldMeds, Lundbeck, Acadia, the American Academy of Neurology, and the Movement Disorders Society. He serves on the editorial boards of the Journal of Parkinson's Disease and Parkinsonism and Related Disorders. S. Wu has received grant support from $\mathrm{NIH}$ and Tourette Association of America and is the site principal investigator for EryDel SpA-sponsored clinical trial for ataxia-telangiectasia. Go to Neurology.org/ $\mathrm{N}$ for full disclosures.

\section{References}

1. Kaalund S, Hogsaa B, Grevy C. Coxa saltans in patients with Ehlers-Danlos syndrome, type III. Scand J Rheumatol 1988;17:229-230.

2. Allen WC, Cope R. Coxa saltans: the snapping hip revisited. J Am Acad Orthop Surg 1995;3:303-308.

\section{Share Your Artistic Expressions in Neurology 'Visions'}

AAN members are urged to submit medically or scientifically related artistic images, such as photographs, photomicrographs, and paintings, to the "Visions" section of Neurology . These images are creative in nature, rather than the medically instructive images published in the NeuroImages section. The image or series of up to six images may be black and white or color and must fit into one published journal page. Accompanying description should be 100 words or less; the title should be a maximum of 96 characters including spaces and punctuation.

Please access the Author Center at NPub.org/authors for full submission information.

\section{Disputes \& Debates: Rapid online correspondence}

The editors encourage comments on recent articles through Disputes \& Debates:

Access an article at Neurology.org/ $N$ and click on "COMMENT" beneath the article header. Responses will be posted within 3 business days.

Before submitting a comment to Disputes \& Debates, remember the following:

- Disputes \& Debates is restricted to comments about studies published in Neurology within the last eight weeks

- Read previously posted comments; redundant comments will not be posted

- Your submission must be 200 words or less and have a maximum of five references; reference one must be the article on which you are commenting

- You can include a maximum of five authors (including yourself) 


\section{Neurology}

\section{Coxa saltans misdiagnosed as functional gait disorder: Two cases \\ Donald L. Gilbert, Alberto J. Espay and Steve W. Wu \\ Neurology 2018;91;276-277 \\ DOI 10.1212/WNL.0000000000005955}

This information is current as of August 6, 2018

$\begin{array}{ll}\begin{array}{l}\text { Updated Information \& } \\ \text { Services }\end{array} & \begin{array}{l}\text { including high resolution figures, can be found at: } \\ \text { http://n.neurology.org/content/91/6/276.full }\end{array} \\ \text { References } & \text { This article cites } 2 \text { articles, } 0 \text { of which you can access for free at: } \\ \text { http://n.neurology.org/content/91/6/276.full\#ref-list-1 } & \text { This article, along with others on similar topics, appears in the } \\ \text { following collection(s): } \\ \text { Conversion } \\ \text { http://n.neurology.org/cgi/collection/conversion } \\ \text { Gait disorders/ataxia } \\ \text { http://n.neurology.org/cgi/collection/gait_disorders_ataxia } \\ \text { Pediatric conversion } \\ \text { http://n.neurology.org/cgi/collection/pediatric_conversion } \\ \text { Information about reproducing this article in parts (figures,tables) or in } \\ \text { its entirety can be found online at: } \\ \text { http://www.neurology.org/about/about_the_journal\#permissions } \\ \text { Information about ordering reprints can be found online: } \\ \text { http://n.neurology.org/subscribers/advertise }\end{array}$

Neurology ${ }^{\circledR}$ is the official journal of the American Academy of Neurology. Published continuously since 1951, it is now a weekly with 48 issues per year. Copyright @ 2018 American Academy of Neurology. All rights reserved. Print ISSN: 0028-3878. Online ISSN: 1526-632X.

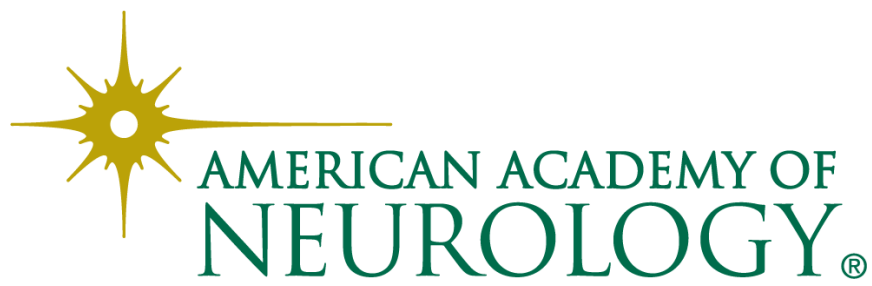

